\title{
( 10$)$
}

II. An Account of the Difcovery of the Corpe of one of the Abbots of Gloucelter. In a Letter from $M r_{\text {o. }}$ John Cooke, Surgieon, of that City, to Charles Marfh, Efq. F.R. and A.S.S.

\section{Read June 21; 1787 ,}

T $\mathrm{N}$ the year 1741, Bifhop Benfon, at his fingle expence, for 1 the better fecuring of the organ, which had been removed fome years before from the South fide of the choir, gave order that a fcreen with proper pillars fhould be erected. During the courfe of this work a ftone coffin containing the corpfe of an abbot was difcovered. Very lately it was thought proper that the whole of the pavement of the body of the church thould be new laid, to which the late Chancellor Benfon very, liberally contributed. It was begun in his life-time. This occafioned the fame coffin to be again expofed, and by this it is alfo to be apprehended that many very antient grave ftones muft be deftroyed and the modern ones removed from the vaults they covered to diftinct places, to effect the uniformity of the flooring. On Monday the $j^{\text {th }}$ of March laft I had palt through the Cathedral at the time when the fame graves were juft expofed. Several perfons were ftanding round the venerable remains, and I was called upon to be a fpectator of that awful fight. My attention was inftantly fixt, and I made a. 1ketch which I have fince perfected. 


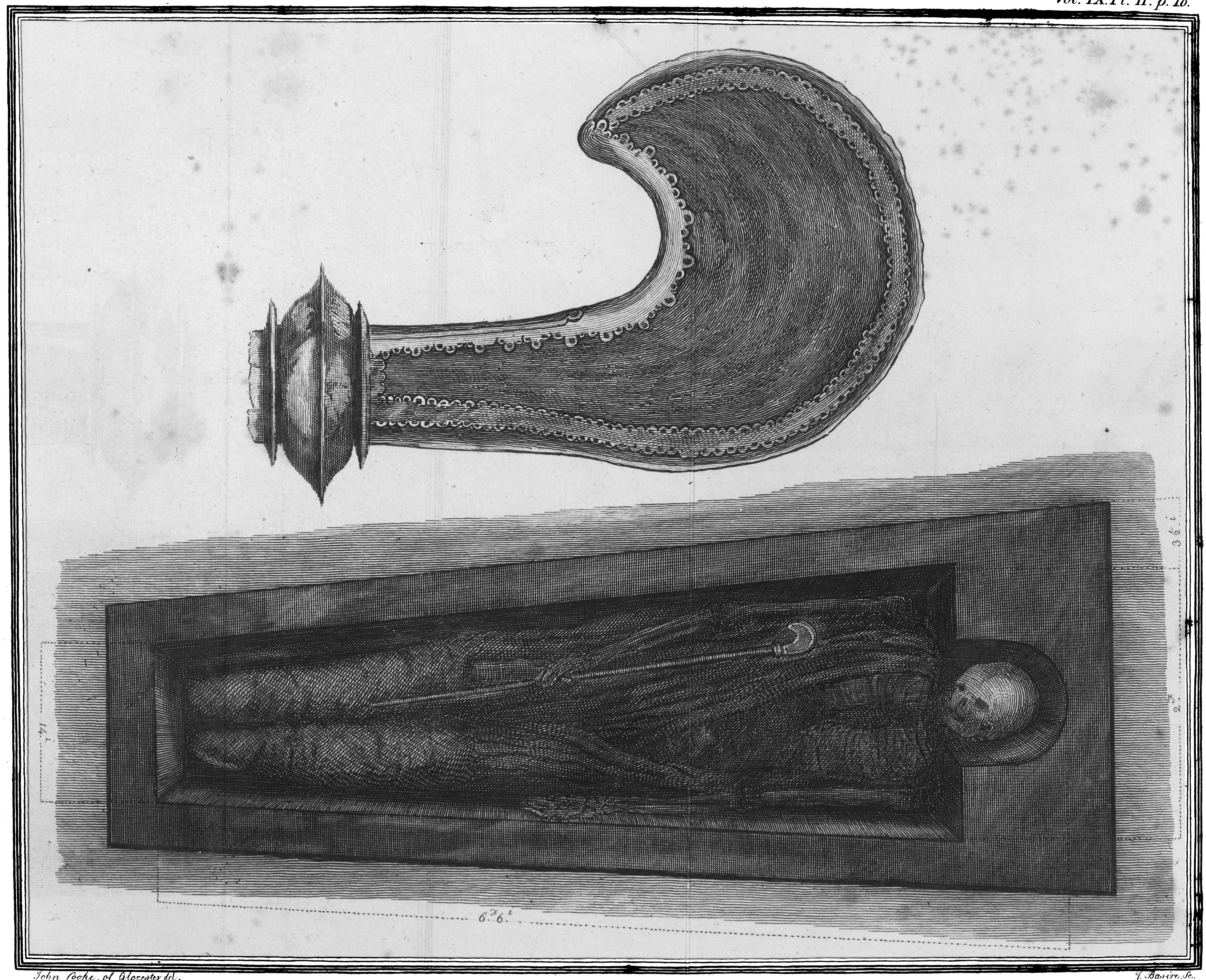


Mr. COORE on the Difcovery of a Corpfe, Ec.

perfected [a]. Had I not accidentally patt at the time of the removal of the ftones which concealed the above coffin, it is probable we might not have had this opportunity of illuftrating the annals of our abbots. The ftone coffin in which the corpfe was laid, was fo near the furface that it had no other covering but the old pavement. The deceafed appeared to have been buried in a robe or gown, and leathern boots: the leather ftill retaining a degree of firmness, nor had it totally loft its elaftic quality. The robe was decayed; for although it had the appearance of folds in feveral parts, yet when toucht it was found to be nothing but powder or duft; the bones were not injured.

Anatomifts tell us, "bodies may be difcovered in vaults feeming perfect and found, becaure the earth in every part of tise animal ftill retains a degree of adhefion, though every other principle is deftroyed, fuch bodies are not putrid (for it does not follow that animals always became putrid after death) yet when expofed to air or on the touch crumble into duft."

There was in the hand of the deceafed a crofier neatly adorned with filver,; which had been gilt and burnithed. It was chiefly of wood, and the ftaff perfectly hard and found. When firft fren by me it was intire. The drawing gives an exact copy of it, as to fize, form, \&c. There were alfo fome remnants of other fymbols, marking the grave of an abbot. Our monaftic hif:' tory informs us, that JOHN WIGMORE, or W $\mathrm{W}_{\mathrm{Y} G M O R}$, prior, was made abbot in $\mathrm{r}_{329}$, and dying on the 12 th of the Kalends of March I 337 , was buried in the South fide, near the entrance of 'the choir, which he inclofed. On this very fpot was this ftone coffin. 'It is of one ftone only, hewn out for the reception of the body. The cavity in which the corpfe, \&c. was laid meafures in length fix feet fix inches and an half; its form as reprefented in the drawing I have fent. The crofier was removed

[a] See plate II.

C 2

by 
by fome perfon in $574 \mathrm{I}$, when it was firft difcovered; but the pious bithop, who confidered the remains of his predeceffor as facred, ordered that it hould be immediately replaced, and commanded that no further liberties might be taken with any thing appertaining to the deceafed. But this humane order was not foriatly obferved, as feveral perfons cut off pieces of the gown or robe, in appearance a kind of ferge. One of the fextons was known to have a remnant of this robe in his pocket for many years. I have heard alfo of the remains of the gloves and other ornaments not very exactly defcribed by thofe who faw them. As to the fketch herewith fent, it has been feen by fome of thofe people, who agree that as well as they can recollect it refembles what they faw at the time of the former opening of the pave ment. Two of thefe perfons faw it after the fecond opening, and all agree in fentiment, and I have the fatisfaction to hear them declare it to be a faithful reprefentation.

I am to add, this ftrongly proves that a dry fituation near tho furface of the ground, where nothing is near the body but a porous frone, is one of the beft prefervatives for the animal frame, and in that fituation the bones may remain without in jury 4:0 years.

On the day following I made another vifit to the place; beheld the grave was filled up with rubbifh, and the facred bones of the venerable old man were fcattered, his kull broken in pieces, and my diftrefs not eafy to be deforibed. Several periniss were ftanding round the grave. A: few days after this one of the vergers called on me at my requet, and brought with him the remains of the head of the abbot's crofier, that I mighe corred my drawing by it if neceffary. The mafter of the workmen has great part of the flick or Ataff which belonged to 
it, and I had from the fexton a piece of the boot. The motive which induced the workmen to difturb the body feems to have been the fearching after fpurs. If this narrative of facts has your approbation, and you think proper to lay it before the Society, you will do me honour.

I remain with great efteem,

Sir, your obliged and obedient humble fervant;

Gloucefter, April $18,17^{8}$.

JOHN COOKE 